\section{Transgenic sticky issues}

\section{Washington}

ANIMAL rights, the release of genetically engineered organisms into the environment, and the effects of large agribusiness companies on the farming industry are the real issues behind the debate over the patenting of animals, according to a report* released last week by the US Congress's Office of Technology Assessment (OTA). Existing regulations can be adapted to address most of the practical considerations of animal patenting, such as whether farmers should pay royalty fees for breeding patented livestock. But the ethical question of whether or not transgenic animals should be subject to patents is a question that may need further clarification, OTA says.

Congress has heard both sides of the debate since the patent office declared in early 1987 that it would not reject patent applications on the sole basis that the invention for which the patent was being sought was an animal. The granting of the first patent for a higher life form last year - to Harvard University, for a transgenic mouse containing human on-

\section{CHEMISTRY}

\section{NERC finds British chemistry ailing \\ London}

CHEMISTRY in Britain is suffering from insufficient investment, inadequate equipment and poor dissemination within the research community of information on facilities available. Those are the main conclusions of a committee set up by the Natural Environment Research Council (NERC) to review the health of chemistry. The report, published this week, concludes that facilities are outdated, and most researchers feel they are lagging far behind their counterparts in other European countries and in the United States. The committee says that because much of the equipment in universities and NERC institutes is old, slow and insensitive, the quality and quantity of data is suffering. This in turn may be leading to the loss of commissioned research contracts.

To remain competitive, Britain must have well-equipped, state-of-the-art laboratories, and this will require a substantial programme of investment in chemical equipment, says the committee. Its report points out that although the cost of equipment is increasing faster than the rate of inflation, its speed and sensitivity are increasing even more rapidly, so the costeffectiveness of new equipment is improving in real terms. At present, even the equipment available is used insufficiently because of severe constraints on travel and subsistence budgets.

Christine McGourty cogenes (see Nature 332,$668 ; 1988$ ) heated up the exchange between patent proponents and those who asserted that animal patenting would lead to animal suffering and higher costs for farmers.

But attempts in the past two years to pass legislation to halt the patenting of additional animals until the ramifications could be worked out - and specifically to exempt researchers and farmers from royalty payment requirements - have floundered. The Animal Legal Defense Fund has also lost the first round in a court battle to overturn the patent office's decision to patent animals.

In the meantime, 44 patent applications covering animals have piled up at the patent office, and the exclusive

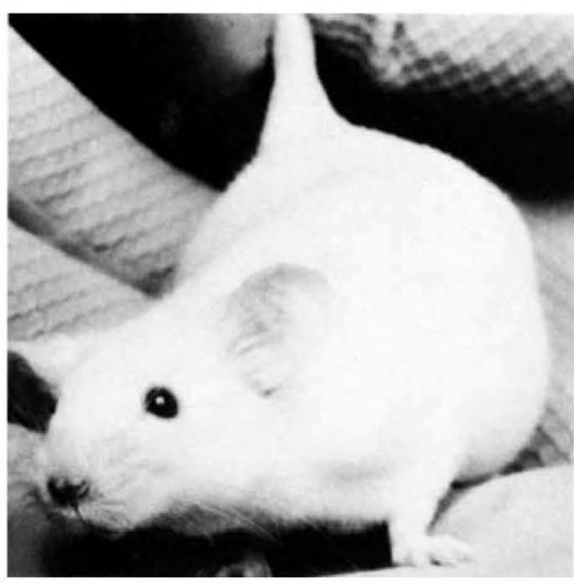

Du Pont's OncoMouse, the only patented animal so far.

licensee of Harvard's patent, Du Pont, is taking orders for its $\$ 50$-apiece OncoMouse, which it plans to begin shipping in May. Other companies are not waiting for patent protection to develop profitmaking genetically engineered animals. Integrated Genetics has formed a collaboration with Tufts University to develop herds of cows capable of excreting human proteins in their milk, and the company Transgenic Sciences has just been formed, and intends to develop animal breeds which produce valuable pharmaceuticals.

Representative Robert Kastenmeier (Democrat, Wisconsin) last week reintroduced bills he put before Congress last year that would create a transgenic animal advisory committee within the Department of Agriculture which would authorize permits to field-test transgenic animals. Kastenmeier's bills also specifically exempt farmers and researchers from paying royalties on patented animals. Kastenmeier says he hopes biotechnology companies and opponents of animal patenting can work out their differences, an acceptable compromise, but

*New Developments in Biotechnology - Patenting Life, Office of Technology Assessment, Washington DC, 1989.
New carp park ahead

\section{Washington}

THE biotechnology review board of the United States Department of Agriculture last week approved the first field-test involving a genetically-engineered fish. Researchers at Auburn University in Alabama have been given permission to introduce carp which contain trout growth hormone genes into a test pond at the university.

The carp were developed through a collaboration between researchers at Auburn, and at Johns Hopkins University in Maryland. Carp containing the trout genes have been shown in the laboratory to grow significantly larger than normal carp, a finding that could have commercial significance for fish farming.

The carp will be kept in a contained pond, with a series of barriers to prevent their escape into open water. As an added precaution, a mechanism has been developed to introduce poison into the water should a fish manage to get beyond one of the barriers.

The Auburn carp is the first transgenic animal to be approved for release into the environment by the Agricultural Biotechnology Research Advisory Committee, which has been charged with developing guidelines for reviewing field-test applications from researchers working under Department of Agriculture grants. The finishing touches are now being put to the committee's guidelines, which should be published in the Federal Register for public comment within the next two months.

The Department of Agriculture is opposed to legislation introduced last week by Representative Robert Kastenmeier (Democrat, Wisconsin) which would require it to set up a separate review board to grant formal permits for field-tests of transgenic animals. Daniel Jones from the Department's Office of Agricultural Biotechnology says that laws already on the books should cover transgenics, with some "fine-tuning" from the new guidelines. Jones says the guidelines will parallel those covering recombinant molecules developed by the National Institutes of Health: they will be compulsory for academic grantees, and industrial researchers are expected to adhere to them voluntarily.

Carol Ezzell

that he will support a halt to animal patenting if the means to address the sticky issues surrounding such patents is not put in place.

The Congressmen who proposed a moratorium on the patenting of animals last year, Representative Charlie Rose (Democrat, North Carolina) and Senator Mark Hatfield (Republican, Oregon), have no plans to introduce their bills again this year.

Carol Ezzel 